\title{
Diocesan Bishop and the Administration of Temporal Goods of the Church ${ }^{1}$
}

\author{
I Made Markus Suma a,1

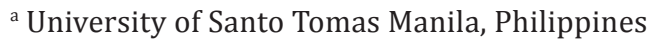 \\ ${ }^{1}$ made.summa@yahoo.co.id
}

\begin{tabular}{|c|c|}
\hline & ( \\
\hline $\begin{array}{l}\text { Keywords: } \\
\text { diocesan Bishop, } \\
\text { temporal goods, } \\
\text { administrator, } \\
\text { administration }\end{array}$ & $\begin{array}{l}\text { To govern his diocese, a diocesan Bishop exercises the threefold power of gov- } \\
\text { ernance, namely legislative, executive and judicial power. As regards the } \\
\text { executive power he can exercise personally or through another person. Ad- } \\
\text { ministrative power becomes the area for the exercise of the executive power, } \\
\text { including in the administration of temporal goods of the diocese and of other } \\
\text { public juridical persons subject to him. In performing a good administration } \\
\text { of the temporal goods of the Church, a diocesan Bishop needs to comply with } \\
\text { pertinent canonical norms as well as to collaborate with respective council or } \\
\text { persons concerned to avoid the abuse of power or misuse of temporal goods. } \\
\text { The matter in question is discussed in the view of canonical analysis. This } \\
\text { research aims at obtaining canonical assessments to the authority of dioce- } \\
\text { san Bishop in administering Church's properties according to their proper } \\
\text { purposes. The first part elaborates in short the juridical power exercised by } \\
\text { the diocesan Bishop. It is followed by the second part, namely discussion on } \\
\text { the temporal goods of the Church. As the focal point, the third part treats the } \\
\text { authority of diocesan Bishop over the temporal goods and then a concise con- } \\
\text { clusion is presented. }\end{array}$ \\
\hline
\end{tabular}

The Catholic Church which coalesces from a divine and a human element (LG, No. 8) needs adequate means to fulfill her mission on earth, that is, to be the universal sacrament of salvation (LG, No. 48) as well as to participate in tria munera Christi. Temporal goods are among other means which have important place in this regard. However, temporal goods of the Church must be administered properly. Canon 1277 speaks of the acts of administration of temporal good of the Church, in particular the temporal goods which belong to particular Church. Every particular Church is governed by a diocesan Bishop, including on the financial matters or the administration of temporal goods. As the administrator of temporal good in his respective diocese (Cf. can. $375, \S 1$ ), what is the authority of diocesan Bishop over the administration of temporal goods of the Church?

In this research, the executive power of diocesan Bishop especially pertaining the 
administration of the temporal goods of the Church is being discussed. The research is divided into five parts. A short exposition concerning diocesan Bishop in particular Church takes the first place. And then several fundamental elements related to temporal goods of the Church are expounded. It is followed by the discussion on the administration of temporal goods. The last part dwells on the authority of diocesan Bishop concerning the administration of temporal goods. The discussion upon the matter in question yields some points as conclusion.

\section{DIOCESAN BISHOP}

By virtue of his episcopal consecration (can. 379) and in hierarchical communion with the college of Bishops and its head (can. $375, \S 2)$, a diocesan Bishop has received divine power to govern a portion of the people of God namely, a particular Church or diocese (can. 368) entrusted to his care. With ordinaria (ordinary), propria (proper) and immediata (immediate) power, he governs his diocese (can. 381, §1).

Having taken the administration of the diocese through canonical possession ad normam can. $382, \S 1$, the diocesan Bishop exercises the threefold power of governance, namely legislative power, executive power and judicial power (can. 391). As regards the executive power he can exercise personally or through another person. Administrative power becomes the area for the exercise of the executive power, including in the administration of temporal goods within the diocese and other public juridical persons subject to the diocesan Bishop (Cf. 1278, 1276, §1, 1279, §2). “Accordingly an integral part of episcopal governance is managing the resources of the diocese in such a way that certain basic principle are observed."2

\section{TEMPORAL GOODS OF THE CHURCH}

For the sake of clarity, several fundamental elements related to temporal goods of the Church need to be clarified at the first place. It begins with the claim of the Church to have innate right (iure nativo) over temporal goods. It is then followed by the use of temporal goods aims at three primary purposes. To attain these purposes, the juridical persons need the capable and eligible administrators of temporal goods. The activities carried out by the administrators are under the authority of the superior.

\section{The Right of the Church}

The Church has claimed the right to acquire, retain, administer and alienate temporal goods proper to her mission. The claim is even emphasized through the qualifying term 'innate'. Canon 1254, $\$ 1$ clearly states, "Ecclesia catholica bona temporalia iure nativo, independenter a civili potestate, acquirere, retinere, administrare et alienare valet ad fines sibi proprios prosequendos." This is the iure nativo of the Church which has been incorporated into the 1983 Code. Consequently, no authority including civil authority can intervene the exercise of this right. It is expressed by the phrase "independenter a civili potestate”.

The Church's right to temporal goods comprises of four acts, that is, to acquire (acquirere), to retain (retinere), to administer (administrare) and to alienate (alienare). In Book V of the 1983 Code, however, these acts classified into three categories, namely to acquire and to retain (cann. 1259-1272, Title I), to administer (cann. 1273-1289, 
Title II) and to alienate (cann. 1290-1298, Title III).

\section{Proper Purposes}

The acquisition, administration and alienation of temporal goods are for particular purposes designated by the Church. The second paragraph of canon 1254 legislates, "Fines vero proprii praecipue sunt: cultus divinus ordinandus, honesta cleri aliorumque ministrorum sustenatio procuranda, opera sacri apostolatus et caritatis, praesertim erga egenos, exercenda." There are three purposes proper for the Church to use temporal goods, namely 1) to provide adequate means for the celebration of divine worship (cultus), 2) to provide decent supports for clergy (clerus) and those lay people whose services are for the Church, and 3) to carry out the works of apostolate and charity especially to the poor (caritas).

The poor has been given profound attention by the Church as it is manifested in the ecclesiastical legislation. Having examined the historical development of prescription of canon 1254 in the Church history and in the context of the case of England, Garret J. Roche denotes, that "the obligations of bishops and clerics toward the poor were enshrined in the law... There were cases of parish rectors being cited in court because of their failure to help the poor through hospitality."3

Indeed, only within the framework of these proper purposes, with serious attention still given to the poor, the temporal goods of the Church can be acquired, administered and alienated. In the words of Thomas J. Green, "All Church goods are to be used for the aforementioned Church purposes (c. 1254, §2; Presbyterorum Ordinis 17).”

\section{Subjects of Temporal Goods}

The Church has claimed to have right over temporal goods. This right does not exclusively belongs to the universal Church. Canon 1258 clarifies the scope as follows, "In the canons which follow, the term Church signifies not only the universal Church or the Apostolic See, but also any public juridical person in the Church..." It should be noted that any public juridical person in the Church has the same right, such as parish ad normam canon 515, §3.

What is that public juridical person? Canon 116, $\$ 1$ expounds it, "Public juridical persons are aggregates of persons or of things which are established by the competent ecclesiastical authority so that, within the limits allotted to them, they might in the name of the Church and in accordance with the provisions of law, fulfill the specific task entrusted to them in view of the public good." Florencio Testera mentions "dioceses, parishes, institutes of consecrated life" which are among those juridical persons as the holders of ecclesiastical patrimony. ${ }^{5}$

It should be noted that all temporal goods, either belong to a diocese, parish or other public juridical persons (Cf. can. 114) are categorized as the temporal goods of the Church (can. 1257). Consequently, their administration are subject to the evaluation, supervision and at times intervention of the ecclesiastical authority ad normam iuris (can. 1276).

\section{Administrators}

To attain the proper purposes of the use of temporal goods, every juridical person (can. 1279) needs to have qualified and competent administrators (can. 1278) 
as well as financial council or at least two counsellors (can. 1280). The administrator is responsible to perform their duties with diligence of a good householder (can. 1284). One of those duties is to render annual accountability to the competent authority of the Church: local Ordinary (cann. 1287 ; $1284, \S 2,8^{\circ}$ ).

Who are considered as administrators of the temporal goods of the Church? It depends on the organization or internal structure of juridical person itself. In fact, the administrator is the person who is directly responsible to the juridical person and holds direct power of governance over it to which the goods belong (can. 1279). For a diocese, for instance, the administrator of its temporal good is the diocesan Bishop or those who are equal in law (can. 381, §2). In analogy it can be applied, that the parish priest is for the parish; to a religious institutes is the religious superior; a shrine is the rector of the said shrine. And above all, by virtue of his primacy, canon 1273 profoundly legislates, "The Roman Pontiff, by virtue of his primacy of governance, is the supreme administrator and steward of all ecclesiastical goods."

\section{ADMINISTRATION OF TEMPORAL GOODS}

The right to administration derives from the right of ownership over the acquired temporal goods. F. Testera points out three functions included in the administration of temporal goods: ${ }^{6}$

1. The preservation and improvement of the goods or assets;

2. The natural or artificial production of fruits or income derived from such property or temporalities;

3. The application of the fruits or income to the proper objectives.
The 1983 Code makes three distinctions pertaining temporal goods of the Church, namely acquisition (cann. 1259-1272), administration (cann. 1273-1289) and alienation (cann. 1290-1299). In fact, the norms on alienation deal not only with alienation in strict sense wherein there is a transfer of ownership over certain temporal goods. Canon 1295, for instance, does not deal with alienation in strict sense, but it treats the matter concerning what John Anthony Renken has identified as 'threatening contract'. It regulates contract which may pose serious 'threat' to the stable patrimony of a particular juridical person. This type of contract does not directly imply the transfer of ownership for a portion or a certain part of the temporal goods of the Church, though it may foresee a 'danger' of transfer of ownership. In this viewpoint, canon 1295 speaks of the administration of the temporal goods of the Church or it may be classified as 'extraordinary administration maioris momen$t i$ ' in the classification introduced by John P. Beal. ${ }^{7}$

For the administration of temporal goods of the Church, Canon Law distinguishes three type acts of administration, namely acts of ordinary administration, acts of administration with major importance and acts of extraordinary administration. ${ }^{8}$ First, it is the ordinary administration. In general, the ordinary administration of temporal goods pertains to the regular or normal administration carried out by the administrator based on the annual planning of the juridical person. Concerning ordinary administration, John P. Beal has proposed a comprehensive definition as follows, "Ordinary administration of Church property is the whole gamut of activities by which the normal, everyday business of a juridic person is carried out. The administrator of the juridic person is empowered in virtue 
of office to carry out these activities without having to consult with or receive the permission or consent of any other authority, council or individual in advance." 9

Similar tone was expressed by F. Testera, "Ordinary acts can be carried out in virtue of the office, whereas the acts of extraordinary administration require a special mandate from the respective superior." 10 It is clear the ordinary administration is conducted by virtue of the office of the administrator within the limits and manners determined by the law or the proper law of the juridical person.

What kind of acts can be classified into ordinary administration? According to F. Testera, "The ordinary administration includes whatever is necessary for the preservation and regular management of the property." ${ }^{11}$ It takes place daily, weekly, monthly or annually with amount or value which is categorized normal. It will not affect the stable patrimony of the juridic person or jeopardize the economic condition of the aforesaid institution. For example, the payment of electric bill, internet, water, regular maintenance of buildings and other office facilities, monthly salaries for the employees and other regular expenses in accord with the annual budget. ${ }^{12}$

Second, the acts of administration with greater importance refers to any transactions which implies greater economic risk to economic condition of the juridical person, that is, specifically refers to diocese. ${ }^{13}$ Accordingly, "such administration consists of those transactions which remain within the domain of the 'ordinary' but are either so infrequent or have such a significant impact on the fiscal well-being of the juridical person that they warrant more careful scrutiny and consideration than usual." ${ }^{14}$ The finan- cial situation of diocese has laid down as a criterion to determine the acts of greater importance, though it is diverse from one place to another, from one diocese to another even in one country. ${ }^{15}$ John P. Beal points out several concrete examples for the acts of administration with greater importance as follows: ${ }^{16}$

1. Establishing norms for parish finance council;

2. Issuing instructions governing the administration of temporal goods within the diocese;

3. Long term investment surplus diocesan funds;

4. Leases of diocesan property not subject to the episcopal conference norms;

5. Initiating fund raising appeals or approving the conduct of fund raising appeals by parishes or other juridical person;

6. Granting pastors and other administrators the faculty to perform acts of extraordinary administration.

Third, it is the acts of extraordinary administration of the temporal goods of the juridical person. It is called extraordinary because the acts "exceed the limits and manner of ordinary administration" which directly or indirectly brings about serious consequences to fiscal condition of the juridical person and thus cannot be decided unilaterally by the administrator. ${ }^{17}$ There are three acts of extraordinary administration mentioned in canon 1277, namely "acts of extraordinary administration, acts where the universal law requires the consent of the finance council and of the college of consultors and acts relating to a foundation where such consent is required." 18 Regarding acts of extraordinary administration of temporal 
goods, F. Testera expounds his opinion with concrete examples:

"Acts that are not included in the concept of ordinary management or exceed its limits and extent. Such acts do not occur regularly but rather in exceptional or even unforeseen cases and are of greater importance. Acts of this kind are, among others, the following: the construction and demolition of buildings, the purchase or sale of real estate and fixed assets or capital, making loans and mortgages, court litigation (c. 1288), the unjustified refusal of an important donation or gift (c. 1267, 2), and in general, all contracts or transactions liable to depreciate or change substantially the patrimony of the Church (c. 1295)."19

The parameter or criteria to consider whether a certain administration is extraordinary or not, must be determined by the statutes of the juridic person or in accordance with the norms enacted by the Bishop's Conference of a given region or nation. The Catholic Bishops' Conference of the Philippines, for instance, has enacted the supplementary norms for the implementation of can. 1277. It reads, "An act of administration is considered extraordinary when it involves the amount of US $\$ 20,000$ and above or its peso equivalent." ${ }^{20}$ Aside from the norms enacted on the basis of the amount of money, Robert T. Kennedy mentions several transactions which have been classified by some Bishops' Conferences as the acts of extraordinary administration, such as "the acceptance of onerous gift or bequest, acquisition of real estate, creation or suppression of institutions, alteration of buildings, relocation of artistic or historic works, or erection of a cemetery." ${ }^{11}$ Consequently, in order to act validly, the administrator are obliged to observe certain solemnities as well as the norms prescribed for valid administration by the statutes of juridical persons or enacted by the Bishops' Conference.

\section{AUTHORITY OF DIOCESAN BISHOP}

As the head of the diocese and administrator of temporal goods of the Church within his confined jurisdiction, ${ }^{22}$ the diocesan Bishop has the authority over juridical persons subject to him, namely his diocese, all parishes within his territory and other juridical persons under the diocesan foundations or belong to public association of Christ's faithful within his diocese. In his diocese, the diocesan Bishop is the person who is primarily responsible to observe the best practice of administration of the temporal goods of the Church. The diocesan Bishop's responsibility takes so great importance especially in the necessary of accountability and credibility of the administration of temporal goods ${ }^{23}$, especially in the midst of questionable financial administration within dioceses. ${ }^{24}$

What is the authority of diocesan Bishop over the administration of temporal good of his diocese and those juridical persons subject to him? To examine this question, it is necessary to make distinction between the diocese as one juridical person which is directly subject to diocesan Bishop and other public juridical persons which are also subject to the diocesan Bishop but managed directly by their respective administrators, namely parishes and other diocesan institutions, such as orphanage, diocesan school, clinic or hospital.

\section{Diocese as a Juridical Person}

To the diocese entrusted to his care, a diocesan Bishop has the authority over the 
administration of all temporal goods of the Church (Cf. cann. 1279 ; 1276). Although he directly governs the diocese, but "the law of the Church does not allow a diocesan bishop in his administration of diocesan financial matters always to act alone." 25 Because of that, the diocesan Bishop has to consult finance council (can. 1281, §2; can. $1277)^{26}$ or to seek the consent of the financial council (cann. $492 ; 1277$ ) and the college of consultors ${ }^{27}$ (can. 502 ; can. 1277).

In canonical tradition, there are three types of administration of temporal goods in a diocese, namely 1) ordinary administration $^{28}, 2$ ) administration with greater importance and 3) extraordinary administration. ${ }^{29}$ The authority of the diocesan Bishop is exercised within these three type acts of administration.

\section{Acts of ordinary administration}

Acts of ordinary administration refer to day-to-day transactions carried out by the administrator or financial administrator. Canon 1281, §1 expressly legislates, "Without prejudice to the provisions of the statutes, administrators act invalidly when they go beyond the limits and manner of ordinary administration, unless they have first received in writing from the Ordinary the faculty to do so." The act of ordinary administration is existing and mentioned by canon $1281, \S 1$, though it is not mentioned in canon 1277. Concerning the act of ordinary administration of temporal goods, F. Testera points out three rights by which the diocesan Bishop like any other Ordinary can exercise his administrative authority over the temporal goods of his diocese and other juridical persons subject to him, namely 1) ius ra- tionem exigendi; 2) ius visitandi and 3) ius praescribendi modum administrationis. ${ }^{30}$

Through ius rationem exigendi, the diocesan Bishop has the right to demand for three essential things: 1) accurate account, 2) updated financial report and 3) supporting evidence of all transactions carried out by the administrative functionaries (Cf. can. 1287).

And then, by exercising ius visitandi, the diocesan Bishop can conduct inspection over the temporal goods of the juridical persons, the official books and other pertinent documents, and check on the observance of rules and laws concerning the conducts of administrators and other personnel (Cf. can. 1276).

A side from that, the diocesan Bishop can exercise the ius praescribendi modum administrationis by which he can issue pertinent norms concerning the effective, accountable and transparent administration of the temporal goods (can. 1276) or having consulted the diocesan financial council, whenever the statutes of the juridical person is silent, the diocesan Bishop can determine the acts of ordinary administration for the juridical person subject to him (can. 1281, §2). Through the pertinent norms he enacted for the juridical person, the diocesan Bishop can impose his will to those administrators under his authority. For instance, he can forbid, among others, the erection of shops, parking places, mortuaries or crypts within the church ground or premises. For the transparent financial accountability, he can prescribe the manner of making bank deposits and withdrawals (for example, it is needed the signature of two or three persons), inventories, last will and testament. ${ }^{31}$ 


\section{Acts of administration with greater im- portance}

Acts of administration of major importance as it is governed by canon 1277 refers to transactions which are beyond the ordinary administration and yet it is not equated to the acts of extraordinary administration. The basic criterion for the diocesan Bishop to consider the act of administration of greater importance is the financial situation of the diocese. ${ }^{32}$ How can the financial situation be appraised? Canon 1277 does not determine or indicate even any criteria to be observed.

Because of that, David J. Walkowiak expresses his opinion, "Actions, which are more importance for one diocese may not necessarily be classified as such for another diocese, due to factors such as size and resources and the nature of the transaction." 33 Walkowiak proposes at least three fundamental criteria to assess the financial situation of a particular diocese, namely the size of the diocese, its financial sources and the nature of the said transaction. If in case, the diocesan Bishop decides to carry out the act of administration with greater importance, he must consult the finance council (can. 492) and the college of consultors (can. 502) ad normam can. 1277. This consultation is prescribed ad validitatem of the said act of administration. According to the prescription of can. 127, $\$ 2,2^{\circ}$, "if advice is required, the Superior's act is invalid if the Superior does not hear those persons." Although he is not obliged to follow their advice, but if these groups unanimously give recommendation, the diocesan Bishop should not act contrary to their advice without overriding reason.

\section{Acts of extraordinary administration}

To carry out an act of extraordinary administration, the diocesan Bishop must seek the consent of the financial council and the college of consultors ad normam canon 1277. There are three acts in which diocesan Bishop has to obtain the consent of the finance council of the diocese and the college of consultors, namely: 1) acts of extraordinary administration, 2) cases specifically mentioned in universal law and 3) cases mentioned in the statutes of a foundation. ${ }^{34}$

Concerning what is considered as an act of extraordinary administration, the Bishops' Conference has to establish pertinent norms ad normam canon 1277 . Several examples can be observed below:

A) Bishops' Conference of Indonesia has established the following norms concerning transactions which affect the temporal goods of the Church: ${ }^{35}$

1. Minimum amount: US $\$ 10.000$ (it can be carried out by the administrator of the juridical person concerned without permission of the diocesan Bishop, unless the Bishop has determined otherwise.)

2. Maximum amount: US $\$ 500.000$ (the diocesan Bishop can give permission having consulted the diocesan financial council and the college of consultors).

3. Beyond the maximum amount: approval of the Holy See is required.

B) The National Conference of Catholic Bishops (NCCB) of the United States promulgated in 1986 the following complementary norms concerning 
the acts of administration of the temporal goods of the Church: ${ }^{36}$

1. To lease church property when the annual lease income exceeds the minimum limit (c. 1295);

2. To lease church property when the value of the leased property exceeds the minimum and the lease is for more than nine (9) years.

C) The Catholic Bishops' Conference of the Philippines (CBCP) also established the norms concerning the extraordinary administration of temporal goods of the Church. It has been regulated, "An act of administration is considered extraordinary when it involves the amount of US $\$ 20.000$ and above or its peso equivalent." 37

\section{Public Juridical Persons Subject to Dioc- esan Bishop}

A side from the authority over the administration of temporal goods in his diocese ad normam canon 1277, the diocesan Bishop as the Ordinary of the place (can. 1281, §2; can. 134) also has indirect administrative authority or supervisory power over the acts of administration of temporal goods other public juridical persons subject to him. Several public juridical persons (cann. 114 ; 116) are subject to diocesan Bishop, such as parishes, diocesan schools under the management of diocesan educational foundation, clinic, hospital, house for the elderly and orphanage which are under the management of diocesan health foundation, institutes of diocesan right or autonomous monastery (can. 638, §4), and public association of Christ's faithful (cann. 314; 312, $\left.\S 1,3^{\circ} ; 315 ; 319, \S 1\right)$.

What is the authority of the diocesan Bishop over the acts of ordinary and ex- traordinary administrations of the temporal goods carried out by the administrator of those public juridical persons subject to him? It is not like the diocese which has three types of acts of administration. In the canonical viewpoint, there are two types of administrations of temporal goods which may be carried out by the administrators of those juridical persons.

\section{Acts of ordinary administration}

The concept about the acts of ordinary administration is worthy to be reemphasized. This kind of acts refers to regular activities or day-to-day transactions carried out by the administrator of a juridical person. If the juridical person is a parish, it is done by the parish priest. If it is a diocesan foundation, it is carried out by the finance officer of the said juridical person. Canon 1281, §1 regulates that the administrator does not need permission from the Superior, i.e., the diocesan Bishop, to carry out acts of ordinary administration in so far the acts are within the limits and manner of ordinary administration determined by the statutes of the juridical person.

To ensure the good practices of administration of temporal goods, the diocesan Bishop, however, can exercise his administrative authority through the threefold rights he holds as the direct and primary administrator of temporal goods within his jurisdiction, namely ius rationem exegendi, ius visitandi and ius praescribendi modum administrationis (Cf. can. 1276). ${ }^{38}$

\section{Acts of extraordinary administration}

The administrator of temporal goods cannot carry out the acts of administration beyond the limit and manner determined by the statutes concerning the acts of ordi- 
nary administration ad normam can. 1281, $\S 1$. There is an exception, however, that the administrator can carry out the aforesaid acts if the Ordinary grants in writing the required faculty.

It should be taken into account the prescription of canon 1281, $\$ 2$ wherein the statutes $^{39}$ are to determine what acts go beyond the limits and manner of ordinary administration. ${ }^{40}$ In case, that the statutes of the juridical persons are silent, it is the authority of the diocesan Bishop, after consulting the finance committee, to determine what acts are considered beyond the ordinary administration for the said juridical person.

The diocesan Bishop, for instance, establishes a monetary limit for the legitimate expenditure for parishes within his diocese. Why are these acts important to be defined clearly? These acts, by their nature, do not occur in regular fashion of economic transactions carried out by the administrator of the juridical person and these acts involve major financial value. Because of that, the permission from the diocesan Bishop as the higher authority in the diocese to be sought. David J. Walkowiak mentions some examples concerning the acts of extraordinary administration carried out by the administrators or financial officers of the juridical persons, such as "purchase of land, construction of new buildings or extensive repair of buildings, expenditures over a designated financial amount, refusal of major bequests, purchase or replacement of major equipment, and the dedication of surplus funds." ${ }^{41}$

\section{CONCLUSION}

As a minister of governance ad normam canon $375 \S 1$ and the head of the diocese (can. 381), a diocesan Bishop holds the administrative power both over his diocese as a juridical person and those juridical persons subject to him. The diocesan Bishop needs to ensure the best or at least the good practices of administration of temporal goods carried out by the administrators and all personnel concerned (can. 1276). Those acts of administrations must be in accordance with three primary purposes of temporal good of the Church, namely adequate means to the celebrations of the divine worship, to provide decent support for clergy and just remuneration given to those who works for the juridical persons, and sustainable means to carry out apostolic works and the works of charity, especially to the needy (can. 1254, $\S 2)$.

The diocesan Bishop has a direct authority over his diocese as a juridical person, either in acts of ordinary administration, acts of administration with greater importance and acts of extraordinary administration of the temporal goods of the Church. Aside from that, the diocesan Bishop also holds the administrative authority or supervisory power over those juridical persons subject to him within his confined jurisdiction. He needs to exercise his authority to ensure the accountable and credible administrations of temporal goods carried out by the administrators and all personnel of respective juridical persons, either in carrying out acts of ordinary or extraordinary administration.

\section{ENDNOTES}

This article was presented by the author to the canonists of Malaysia and Singapore during their annual gathering held on April 23-26, 2018 in Penang Diocese, Malaysia.
Thomas J. Green, Shepherding the Patrimony of the Poor: Diocesan and Parish Structures of Financial Administration, The Jurist 56 (1997): 706. 
G.J. Roche, "The Poor and Temporal Goods in Book V of the Code", The Jurist 55 (1995): 308-309.

4 Thomas J. Green, "Shepherding the Patrimony of the Poor: Diocesan and Parish Structures of Financial Administration", 707.

5 Florentino Testera, "Ecclesiastical Financial Management", dalam Selected Readings in Canon Law 1, ed. Jose Maria B. Tinoko, 139. Philippines: Santo Tomas University Press, 1989.

6 Florentino Testera, "Ecclesiastical Financial Management", 140.

7 John P. Beal, "Ordinary, Extraordinary and Something in between: Administration of the Temporal Goods of Dioceses and Parishes", The Jurist 72 (2012): 125. Beal enumerates several transactions which might seriously threaten the stable patrimony of a juridical person, such as dioceses or parishes, "1. Mortgaging church property to secure a loan whose value exceeds the upper limit established by the episcopal conference in accord with canon $1292, \S_{1} ; 2$. Incurring substantial indebtedness, whether secured or unsecured, in excess of the upper limit established by the episcopal conference in accord with canon $1292, \S_{1} ; 3$. Acting as guarantor or surety for loans made to other juridic persons or church-related entities in excess of the upper limit established by the episcopal conference in accord with canon $1292, \oint 1 ; 4$. Restructuring the civil law status of a public juridic person in a way that transfers operational control while retaining canonical ownership; 5. Settlement of litigation in frequently recurring matters which may set a standard or precedent for future settlements or judgments; 6. Filing for bankruptcy protection; 7. Acquiring or selling real property whose own value does not exceed the limits set in accord with canon $1292, \S 1$, but the impact of whose acquisition or sale is to seriously reduce the value of other stable patrimony."

8 John P. Beal, "Ordinary, Extraordinary and Something in between: Administration of the Temporal Goods of Dioceses and Parishes", 112. J.P. Beal mentions four types of administration, namely "ordinary administration simpliciter, ordinary administration of greater importance (maior momenti), extraordinary administration, and might be called extraordinary administration of greater importance."

9 John P. Beal, "Ordinary, Extraordinary and Something in between: Administration of the Temporal Goods of Dioceses and Parishes", 112.

10 Florentino Testera, "Ecclesiastical Financial Management", 141.

11 Florentino Testera, "Ecclesiastical Financial Management", 141.

12 Florentino Testera, "Ecclesiastical Financial Management", 141. F. Testera points out several concrete examples, "These acts which occur daily or periodically, monthly, quarterly, yearly, and are absolutely necessary for the customary transaction of business such as the payments of current bills and wages, the making of ordinary repairs, the collection or disposal of earnings or fruits, the deposit and withdrawal of funds, the collection of receivables, the making of requires sales and purchases."

13 Can. 1277 legislates, "In carrying out acts of administration which, in the light of the financial situation of the diocese, are of major importance, the diocesan Bishop must consult the finance committee and the college of consultors."

14 John P. Beal, "Ordinary, Extraordinary and Something in between: Administration of the Temporal Goods of Dioceses and Parishes", 113.

15 Francis G. Morrisey, "Ordinary and Extraordinary Administration", The Jurist 48 (1988): 716.

16 John P. Beal, "Ordinary, Extraordinary and Something in between: Administration of the Temporal Goods of Dioceses and Parishes", 124.
17 John P. Beal, "Ordinary, Extraordinary and Something in between: Administration of the Temporal Goods of Dioceses and Parishes", 113.

18 Francis G. Morrisey, "Ordinary and Extraordinary Administration", 717.

19 Florentino Testera, "Ecclesiastical Financial Management", 141-142.

20 E. Caparros et al (eds.), Code of Canon Law Annotated, (Montréal: Wilson \& Lafleur Limitée - Woodridge: Midwest Theological Forum) 2004: 1816-1817 ; Cf. the National Conference of Catholic Bishops (NCCB), USA, has regulated the acts of extraordinary administrations ad normam can. 1277. But, the norms enacted actually regulate the acts of alienation (no. 1-3), contract which might jeopardize the stable patrimony (no. 4) and acts of leasing (n. 5-6).

21 R.T. Kennedy, "Book V: Temporal Goods of the Church", dalam New Commentary on the Code of Canon Law, eds., John P. Beal et al., 1480. Bangalore: Theological Publications in India, 2003.

22 Can. 375 legislates, "By divine institution, Bishops succeed the Apostles through the Holy Spirit who is given to them. They are constituted Pastors in the Church, to be the teachers of doctrine, the priests of sacred worship and the ministers of governance." As integral part of the power of governance, the diocesan Bishop hold the threefold power, namely the legislative power, executive and judicial power (can. 391, 1). The exercise of the executive power is carried out by the diocesan Bishop through the acts of administration, including in the administration of the temporal goods of the Church within his jurisdiction (cf. can. 1279).

23 L.Y. Medroso, "Administration of Temporal Goods of the Church and Transparency", Philippine Canonical Forum 6 (2004): 241.

24 Thomas J. Green, The 2004 Directory on the Ministry of Bishops: Reflection on Episcopal Governance in A Time of Crisis, 143.

25 Robert T. Kennedy, "Book V: Temporal Goods of the Church", p. 1478. Kennedy explains the rationale behind this ecclesiastical legislation, "first, to guard against the danger of grave harm to the financial condition of a diocese from decisions hastily made in the absence of accurate and adequate information from truly knowledgeable and skilled experts; second, to free the diocesan Bishop from the felt need to spend inordinate amounts of time attending to financial matters to the neglect of his many responsibilities in the teaching and sanctifying offices of the Church and in the nonfinancial areas of the governing office."

26 Thomas J. Green, The 2004 Directory on the Ministry of Bishops: Reflection on Episcopal Governance in A Time of Crisis, 136. Thomas J. Green recited AS concerning presbyteral council as follows, "The Council is a privileged locus of bishop-presbyteral communication and collaboration (AS 182)."

27 Thomas J. Green, The 2004 Directory on the Ministry of Bishops: Reflection on Episcopal Governance in A Time of Crisis, 137. Referred to Apostolorum Successores, T.J. Green mentions that AS stresses the college's input in major patrimonial matters and its occasional deliberative role; like the chapter, it plays an especially significant consultative role sede vacante but less on sede plena."

28 It is mentioned and regulated in can. 1281, $\S 1$.

29 These two acts of administration are governed by the prescriptions of can. 1277.

30 Florentino Testera, "Ecclesiastical Financial Management", 146.

31 Florentino Testera, "Ecclesiastical Financial Management", 146.

32 Francis G. Morrisey, "Ordinary and Extraordinary Administration", 716-717. Francis G. Morrisey expounds, "It would 
seem that because of the wording of the canon, the basic criterion to be applied in such instances would be the amount of money involved in the transaction and not the manner of proceeding with the transaction."

33 David J. Walkowiak, "Chapter Sixteen: Ordinary and Extraordinary Administration", dalam Church Finance Handbook, eds. Kevin E. Mckenna et al., 188. Washington D.C.: Canon Law Society of America, 1999

34 Francis G. Morrisey, "Ordinary and Extraordinary Administration", 717.

35 J. Liku-Ada', Statuta Keuskupan Agung Makassar, Keuskupan Agung Makassar, Indonesia 2001, p. 67. It should be noted that these norms do not mention what kind of act to be considered acts of extraordinary administration and also do not distinguish the act of administration and the act of alienation of temporal goods as it is governed by the 1983 Code. The term used is quite general, that is, "transaction" which affects the temporal goods of the Church. The norms concern only the value of the transaction.

36 David J. Walkowiak, "Chapter Sixteen: Ordinary and Extraordinary Administration”, 189.

\section{REFERENCE}

Beal, John P. “Ordinary, Extraordinary and Something in between: Administration of the Temporal Goods of Dioceses and Parishes." The Jurist 72 (2012): 109-129.

Caparros, E. et al. (eds.), Code of Canon Law Annotated. Montréal: Wilson \& Lafleur Limitée - Woodridge: Midwest Theological Forum, 2004.

F. Testera, "Ecclesiastical Financial Management." dalam Selected Readings in Canon Law 1, ed. Jose Maria B. Tinoko, 137-152. Philippines: Santo Tomas University Press, 1989.

Green, Thomas J. "The 2004 Directory on the Ministry of Bishops: Reflection on Episcopal Governance in A Time of Crisis". Studia Canonica 41 (1997): 117-151.

Green, Thomas J. "Shepherding the Patrimony of the Poor: Diocesan and Parish Structures of Financial Administration". The Jurist 56 (1997): 706-734.

Kennedy, Robert T. "Book V: Temporal Goods of the Church." dalam New Commentary on the Code of Canon Law, eds. J.P. Beal et al, 1451-
37 E. Caparros et al. (eds.), E. Caparros et al (eds.), Code of Canon Law Annotated, 1765

38 Florentino Testera, "Ecclesiastical Financial Management", 146.

39 Can. 94, §1 reads, "Statutes properly so-called are regulations which are established in accordance with the law in aggregate of persons or of things, whereby the purpose, constitution, governance and manner of acting of these bodies are defined."

40 Francis G. Morrisey, "Ordinary and Extraordinary Administration", 725. "It would seem that the appropriate place to find determination regarding ordinary and extraordinary administration would be in the statutes of the association (see. Can. 325). When recognizing such statutes, diocesan bishops could be watchful to see that they provide for such eventualities. In addition to matters requiring more extensive internal control, the text should also determine those instances when the administrator requires written permission of the ordinary."

41 David J. Walkowiak, "Chapter Sixteen: Ordinary and Extraordinary Administration”, 193.

1525. Bangalore: Theological Publications in India, 2003.

Liku-Ada', John. Statuta Keuskupan Agung Makassar. Indonesia: Keuskupan Agung Makassar, 2001.

Medroso, Leonardo Y. "Administration of Temporal Goods of the Church and Transparency." Philippine Canonical Forum 6 (2004): 241246.

Morrisey, Fancis G., "Ordinary and Extraordinary Administration: Canon 1277." The Jurist 48 (1988): 709-726.

Renken, John Antony, "Contracts Threatening Stable Patrimony: the Discipline and Application of Canon 1295", Studia Canonica 45 (2011): 501-519.

Roche, Garret J., "The Poor and Temporal Goods in Book V of the Code." The Jurist 55 (1995): 299-348.

Walkowiak, David J. "Chapter Sixteen: Ordinary and Extraordinary Administration." dalam Church Finance Handbook, eds. Kevin E. Mckenna et al., 185-206. Washington D.C.: Canon Law Society of America, 1999. 